Vol. 1 No. 2 September 2021 e-ISSN : 2797-3344 P-ISSN : 2797-3336

\title{
PENINGKATAN HASIL BELAJAR SISWA PADA SIFAT LARUTAN GARAM MELALUI PENERAPAN DISCOVERY LEARNING PADA SISWA KELAS XI MIPA-3
}

\author{
RETNO LUKITASARI
}

SMA Negeri 2 Jember

Email : retnoluki87@gmail.com

\begin{abstract}
ABSTRAK
Penelitian ini bertujuan untuk meningkatkan hasil belajar siswa kelas XI MIPA- 3 SMAN 2 Jember tahun pelajaran 2017/2018 melalui penerapan discovery learning pada materi sifat larutan garam. Penelitian ini merupakan Penelitian Tindakan Kelas (PTK) yang dilakukan dalam dua siklus penelitian yaitu siklus I dan siklus II. Subjek penelitian adalah siswa kelas XI MIPA-3 SMAN 2 Jember yang berjumlah 36 siswa, terdiri 17 siswa laki-laki dan 19 siswa perempuan. Teknik pengumpulan data pada penelitian ini menggunakan observasi untuk pelaksanaan proses pembelajaran dan tes untuk mengetahui hasil belajar siswa. Berdasarkan hasil penelitan dapat disimpulkan bahwa penerapan discovery learning dapat meningkatkan hasil belajar siswa materi sifat larutan garam. Pada siklus I persentase ketuntasan belajar siswa sebesar 58,33\% (21 siswa) dan meningkat pada siklus II, persentase ketuntasan belajar siswa sebesar $88,88 \%$ (32 siswa). Terjadi peningkatan yang signifikan dari siklus I ke siklus II yaitu $30,50 \%$.
\end{abstract}

Kata kunci : Discovery Learning, hasil belajar

\section{ABSTRACT}

This study aims to improve student learning outcomes in class XI MIPA-3 SMAN 2 Jember in the 2017/2018 academic year through the application of discovery learning to the material properties of salt solutions. This research is a Classroom Action Research (CAR) which was conducted in two research cycles, namely cycle I and cycle II. The research subjects were students of class XI MIPA-3 SMAN 2 Jember, totaling 36 students, consisting of 17 male students and 19 female students. Data collection techniques in this study used observation for the implementation of the learning process and tests to determine student learning outcomes. Based on the results of the research, it can be concluded that the application of discovery learning can improve student learning outcomes regarding the properties of salt solutions. In the first cycle the percentage of student learning completeness was $58.33 \%$ (21 students) and increased in the second cycle, the percentage of student learning mastery was $88.88 \%$ (32 students). There was a significant increase from cycle I to cycle II, namely $30.50 \%$.

Keywords: Discovery Learning, learning outcomes

\section{PENDAHULUAN}

Guru sebagai salah satu unsur dalam pendidikan, tenaga profesional yang dituntut untuk menguasai bahan ajar maupun strategi pembelajaran.Pendekatan pembelajaran yang dilakukan saat proses belajar- mengajar menentukan pengembangan kompetensi siswa. Guru dapat berperan sebagai pendidik, pengajar, motivator dan fasilitator untuk membantu siswa agar kompetensinya dapat berkembang secara maksimal.

Mata pelajaran kimia di sekolah dikembangkan dengan mengacu pada perkembangan ilmu pengetahuan alam, dimana siswa tidak hanya dituntut untuk memiliki kemampuan dalam berhitung tetapi juga dituntut untuk menguasai konsep. Untuk menguasai konsep- konsep, kimia mempunyai metode yang berbeda satu dengan yang lainnya sesuai dengan materi yang dipelajari dan tujuan yang hendak dicapai. Penting sekali bagi guru untuk memahami proses belajar siswa agar guru dapat menyediakan lingkungan belajar yang tepat dan sesuai bagi siswa.

Peneliti sebelum melakukan penelitian memperhatikan situasi dan kondisi belajar tempat penelitian diadakan. Berdasarkan observasi yang dilakukan di SMAN 2 Jember, peneliti mewancarai siswa kelas XI mengenai minatnya terhadap pelajaran kimia, sebagian siswa 
berpendapat bahwa kimia merupakan pelajaran yang kurang diminati serta merupakan pelajaran yang sulit karena siswa hanya mengandalkan hafalan rumus.

Pada mata pelajaran kimia kelas XI semester genap salah satu materi yang dipelajari adalah sifat larutan garam. Dalam mempelajari sifat larutan garam, siswa dituntut bukan hanya sekedar hafalan saja tetapi kegiatan yang memerlukan pengamatan/ eksperimen di laboratorium

Peneliti melakukan penelitian tindakan kelas yang dilakukan di kelas XI MIPA-3 SMAN 2 Jember yang berumlah 36 siswa, 17 siswa laki- laki dan 19 siswa perempuan. Berdasarkan pengamatan selama pembelajaran dari data hasil ulangan harian ternyata masih rendah. Dari 36 siswa ada 15 siswa $(41,67 \%$ ) yang belum mencapai KKM berarti belum tuntas dan 21 siswa $(58,33 \%)$ yang sudah mencapai KKM berarti sudah tuntas. Besaran KKM untuk mata pelajaran kimia ditetapkan 80. Perolehan hasil belajar tersebut belum menggambarkan ketercapaian kompetensi siswa. Kelas dikatakan tuntas belajarnya (ketuntasan klasikal) jika dalam kelas tersebut terdapat $\geq 85 \%$ siswa yang telah tuntas belajarnya ( Trianto, 2009 ).

Rendahnya kemampuan siswa dalam memahami konsep kimia ditandai dengan halhal berikut:

1) Rendahnya motivasi siswa dalam mengikuti proses belajar- mengajar 2) Dominan guru dalam proses pembelajaran menyebabkan siswa lebih banyak bersifat pasif 3) Metode pembelajaran yang diterapkan kurang bervariasi 4) Guru belum menggunakan laboratorium sebagai sarana untuk memahami konsep.

Dari permasalahan tersebut maka diperlukan upaya untuk mengatasi masalah tersebut untuk meningkatkan kualitas pembelajaran. Oleh karena itu, perlu dilakukannya suatu penelitian tindakan kelas ( PTK) dalam rangka memperbaiki mutu praktik pembelajaran di kelas.

Salah satu upaya untuk mengatasi permasalahan tersebut adalah dengan menerapkan model pembelajaran Discovery Learning atau model penemuan pada materi sifat larutan garam. Model Discovery Learning merupakan model pembelajaran yang berpikir kritis dan menitik beratkan pada pengalaman langsung melalui kegiatan laboratorium sehingga kegiatan pembelajaran dan hasil belajar mengalami peningkatan. Kegiatan pembelajaran dengan cara penemuan dapat meningkatkan hasil belajar siswa dalam belajar kimia dengan cara yang lebih menyenangkan daripada metode konvensional.

Menurut Sudjana (2010), bahwa hasil belajar adalah kemampuan yang dimiliki siswa setelah menerima pengalaman belajar. Kemampuan - kemampuan tersebut mencakup aspek kognitif, afektif dan psikomotorik. Hasil belajar dapat dilihat melalui melalui kegiatan evaluasi yang bertujuan untuk mendapatkan data pembuktian yang akan menunjukkan tngkat kemampuan siswa dalam mencapai tujuan pembelajaran.Tujuan penilaian hasil belajar 1)mendeskripsikan kecakapan belajar siswa sehingga dapat diketahui kelebihan dan kekurangannya dalam berbagai bidang studi atau mata pelajaran yang ditempuhnya.Dengan pendeskripsian kecakapan tersebut dapat diketahui pula posisi kemampuan siswa dibandingkan dengan siswa lainnya 2) mengetahui keberhasilan proses pendidikan dan pengajaran di sekolah yakni seberapa jauh keefektifannya dalam mengubah tingkah laku siswa ke arah tujuan pendidikan yang diharapkan 3) menentukan tindak lanjut hasil penilaian yakni melekukan perbaikan dan penyempurnaan dalam hal program pendidikan dan pengajaran serta sistem pelaksanaannya 4) memberikan pertanggungjawaban "accountability" dari pihak sekolah kepada pihak- pihak yang berkepentingan.

Beberapa penelitian menjelaskan bahwa Discovery Learning merupakan model pembelajaran yang sesuai untuk meningkatkan hasil belajar siswa. Menurut Kadri (2015), model Discovery Learning yaitu model pembelajaran yang memusatkan pada pemahaman terhadap suatu pengetahuan melalui keikutsertaannya secara aktif dalam kegiatan pembelajaran . Dengan model pembelajaran ini,siswa secara aktif menemukan ide- ide dan konsep baru yang akhirnya akan meningkatkan hasil belajar. Menurut Fitriyah (2015), model discovery learning itu akan menciptakan siswa yang turut aktif dan memperlihatkan ikutsertaannya,siswa dapat melakukan pendekatan dengan sistem tanya jawab,menciptakan partisipasi yang efisien, konsep 
yang dipelajari menjadi lebih bermanfaat, kemampuan akan lebih mudah diterapkan dalam pembelajaran. Dalam mengaplikasikan model discovery learning guru berperan sebagai pembimbing dengan memberikan kesempatan kepada siswa untuk belajar secara aktif, sebagaimana pendapat guru harus dapat membimbing dan mengarahkan kegiatan belajar siswa sesuai dengan tujuan (Sardiman, 2008). Kondisi seperti ini ingin merubah kegiatan belajarmengajar yang teacher oriented menjadi student oriented. Dalam model discovery learning bahan ajar tidak disajikan dalam bentuk akhir, siswa dituntut untuk melakukan berbagai kegiatan menghimpun informasi, membandingkan, mengkategorikan, menganalisis, mengintegrasikan, mereorganisasikan bahan serta membuat kesimpulan.

Menurut Halimatus Sa'diah (2017) dengan metode pembelajaran discovery learning diharapkan siswa mendapat pengalaman langsung dalam menentukan jenis garam yang mengalami hidrolisis dalam air dan $\mathrm{pH}$ larutan garam, lebih mampu memahami konsep dari materi yang sedang dipelajari sehingga akan berpengaruh pada peningkatan hasil belajarnya.

\section{METODE PENELITIAN}

Penelitian yang digunakan adalah penelitian tindakan kelas (PTK). Desain penelitian yang digunakan adalah desain model Stephen Kemmis dan Mc.Taggart, yaitu model skema yang menggunakan suatu siklus spiral. Siklus ini terdiri dari perencanaan, tindakan, observasi dan refleksi yang kemudian diikuti siklus berikutnya. Penelitian ini dilaksanakan menggunakan model discovery learning dalam dua siklus pembelajaran. Penelitian dilaksanakan pada semester genap tahun ajaran 2017/2018 di SMAN 2 Jember dengan subjek penelitian yaitu 36 siswa kelas XI MIPA- 3 yang terdiri dari 17 siswa laki- laki dan 19 siswa perempuan. Peran peneliti adalah sebagai guru kimia yang mengajar siswa pada materi hidrolisis garam. Guru dibantu oleh sesama guru kimia sebagai observer. Berikut ini gambaran desain penelitian tindakan kelas menurut (Stephen Kemmis \&Mc.

Taggart,1998) terlihat pada gambar 1 di bawah ini.

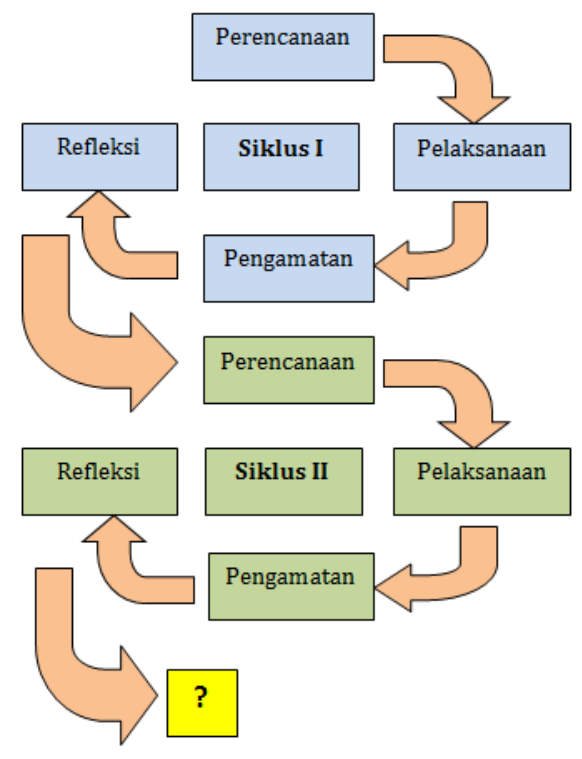

\section{Gambar1. Desain Penelitian Tindakan Kelas}

Teknik pengumpulan data dalam penelitian ini yaitu: 1) observasi, merupakan pengamatan dan pencatatan kegiatan yang dilakukan secara sistematis untuk mengamati perilaku dan aktivitas siswa dan guru selama proses pembelajaran berlangsung dengan model discovery learning. 2) tes, digunakan untuk mengetahui penguasaan materi pembelajaran oleh siswa serta mengukur besarnya peningkatan hasil belajar siswa. Bentuk tes yang digunakan dalam penelitian ini adalah pilihan ganda. 


\section{HASIL PENELITIAN DAN PEMBAHASAN}

a. Hasil Penelitian

Siklus 1 pertemuan pertama

Pada siklus 1 kegatan pendahuluan dilakukan dengan guru mengkondisikan siswa untuk siap belajar, menyampaikan tujuan mempelajari hidrolisis dan membagi siswa ke dalam kelompok praktikum.Setelah itu guru memberikan stimulus dengan menunjukkan beberapa contoh garam dan siswa mengamati beberapa garam tersebut.Kemudian siswa diminta untuk bertanya yang berkaitan dengan contoh beberapa garam dan guru memberikan tanggapan terhadap jawaban siswa. Pada tahap berikutnya siswa merancang untuk melakukan percobaan penentuan jenis garam yang mengalam hidrolisis, mengolah dan menganalisa data, memverifikasi hasil pengolahan data.

Pada akhir kegiatan inti siswa menarik kesimpulan tentang hidrolisis sebagian dan total,kemudian mempresentasikan hasil diskusi kelompok. Kegiatan penutup, guru memberi penguatan dan menyampaikan materi untuk pertemuan berikutnya.

Siklus 1 pertemuan kedua

Pada pertemuan kedua,kegiatan pendahuluan dilakukan dengan guru mengecek keadaan siswa,menyampaikan teknik penilaian.Setelah itu guru memberikan stimulus dengan memberikan beberapa contoh reaksi hidrolisis. Kemudian siswa diminta mengajukan pertanyaan tentang beberapa reaksi hidrolisis yang diberikan guru. Pada tahap berikutnya siswa secara berkelompok mengerjakan LKS tentang perhitungan $\mathrm{pH}$ hidrolisis .Pada akhir kegiatan inti siswa menarik kesimpulan dan mempresentasikan hasil diskusi kelompok. Pada kegiatan penutup, guru memberikan penguatan tentang $\mathrm{pH}$ hidolisis.Sebelum pembelajaran berakhir diadakan post test tentang hidrolisis untuk mengukur pemahaman siswa terhadap materi yang telah dijelaskan.

Hasil data evaluasi pada siklus pertama dapat dilihat pada tabel 2.

Tabel 1. Hasil evaluasi belajar siswa pada siklus 1

\begin{tabular}{|l|l|l|}
\hline No & Uraian & Hasil \\
\hline 1. & Nilai tertinggi & 90 \\
\hline 2. & Nilai terendah & 50 \\
\hline 3. & Nilai rata- rata tes hasil belajar & 76,11 \\
\hline 4. & Jumlah siswa yang tuntas belajar & 21 \\
\hline 5. & Jumlah siswa yang tidak tuntas belajar & 15 \\
\hline 6. & Persentase ketuntasan belajar & $58,33 \%$ \\
\hline
\end{tabular}

Berdasarkan pada tabel 2 di atas, bahwa hasil evaluasi belajar siswa diperoleh nilai ratarata kelas sebesar 76,11 dan siswa yang tuntas belajar sebesar 58,33\% atau 21 siswa dari 36 siswa. Hal ini menunjukkan bahwa secara klasikal siswa belum tuntas belajar. Dengan melihat hasil evaluasi diatas,maka perlu diadakan tindakan lebih lanjut dengan melakukan proses pembelajaran pada siklus II.

\section{Siklus II pertemuan pertama}

Pada siklus ini kegiatan pembelajaran hampir sama dengan siklus 1,lebih difokuskan untuk perbaikan terhadap kendala- kendala yang ada pada siklus I. Pada pertemuan pertama,siswa dibagi dalam beberapa kelompok, kemudian guru memberikan stimulus dengan menayangkan video tentang beberapa contoh garam. Setelah itu guru memberikan umpan balik dengan mengajukan beberapa pertanyaan tentang contoh garam tersebut. Pada tahap berikutnya siswa melakukan percobaan penentuan jenis garam,mengolah,menganalisa dan memverifikasi hasil pengolahan data.

Pada akhir kegiatan siswa menarik kesimpulan tentang penentuan jenis garam dan masing- masing kelompok mempresentasikan hasil diskusi kelompok.Guru memberikan 
reward kepada kelompok yang menjawab dengan benar. Pada kegiatan penutup,guru memberikan tanggapan dan penguatan tentang materi hidrolisis.

Siklus II pertemuan kedua

Pada pertemuan kedua ini guru memberikan perhatian yang lebih pada siswa yang mengalami kesulitan dan belum mencapai ketuntasan pada siklus I.Setelah guru memberikan stimulus dengan memberikan contoh reaksi hidrolisis,guru memberikan umpan balik dengan mengajukan pertanyaan tentang reaksi hidrolisis.Kemudian siswa diberikan LKS tentang reaksi perhitungan hidrolisis. Guru memastikan siswa sudah paham tentang reaksi hidrolisis dengan cara berkeliling pada masing- masing kelompok. Pada akhir kegiatan, guru dan siswa menyimpulkan tentang perhitungan hidrolisis dan guru memberikan penguatan. Setelah itu guru memberikan post tes sebelum kegiatan pembelajaran berakhir untuk mengukur pemahaman siswa terhadap materi yang telah diberikan.

Hasil data evaluasi pada siklus II dapat dilihat pada tabel 3.

Tabel 2. Hasil evaluasi belajar siswa pada siklus II

\begin{tabular}{|l|l|l|}
\hline No & Uraian & Hasil \\
\hline 1. & Nilai tertinggi & 90 \\
\hline 2. & Nilai terendah & 65 \\
\hline 3. & Nilai rata- rata tes hasil belajar & 83,19 \\
\hline 4. & Jumlah siswa yang tuntas belajar & 32 \\
\hline 5. & Jumlah siswa yang tidak tuntas belajar & 4 \\
\hline 6. & Persentase ketuntasan belajar & $88,88 \%$ \\
\hline
\end{tabular}

Berdasarkan data pada tabel 3 diatas,bahwa hasil evaluasi belajar siswa diperoleh nilai rata- rata kelas sebesar 83,19 dan siswa yang tuntas belajar sebesar 88,88\% atau 32 siswa dari 36 siswa. Hal ini menunjukkan bahwa secara klasikal siswa sudah tuntas belajar secara klasikal karena sudah memenuhi syarat di atas kriteria ketuntasan klasikal 85\%, maka penelitian berakhir di siklus 2 .

Perbandingan hasil evaluasi belajar antar siklus.

Perbandingan hasil evaluasi belajar antar siklus bertujuan untuk mengetahui peningkatan yang terjadi dari siklus I ke siklus II. Perbandingan hasil evaluasi belajar antar siklus dapat dilihat pada gambar 2.

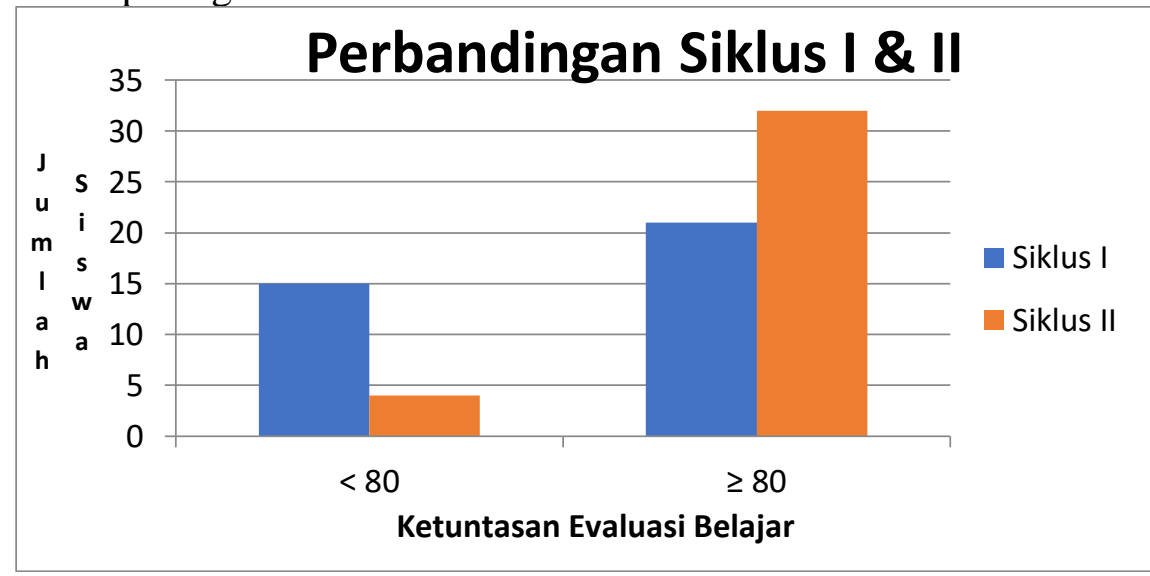

Gambar 2. Histogram peningkatan ketuntasan hasil evaluasi belajar siklus I \& II

Berdasarkan gambar 2, dapat disimpulkan bahwa terdapat peningkatan persentase siswa yang tuntas dari siklus I ke siklus II. Peningkatan ketuntasan dari siklus I ke siklus II sebesar 30,50\%.

b. Pembahasan 


\section{Vol. 1 No. 2 September 2021 e-ISSN : 2797-3344 P-ISSN : 2797-3336}

Pada sikus I rata- rata hasil belajar sebesar 76,11 dan setelah dilakukan perbaikan pembelajaran pada siklus II rata- rata hasil belajar meningkat menjadi 83,19.Peningkatan hasil belajar siswa juga tampak dari persentase ketuntasan belajar siswa secara klasikal, siklus I sebesar $58,33 \%$ dan setelah dilakukan perbaikan pembelajaran pada siklus II meningkat menjadi $88,88 \%$.

Hasil yang diperoleh pada siklus I belum memenuhi standar ketuntasan minimal disebabkan karena 1) selama proses pembelajaran pada siklus I, masih ada beberapa siswa yang masih pasif, kurang antusias dan kurang bersemangat dalam mengikuti kegiatan proses belajar dengan model discovery Learning; 2) ada juga beberapa siswa yang hanya diam ketika diskusi kelompok walaupun belum mengerti tentang materi yang sedang dipelajari; 3)pada waktu praktikum,ada kelompok yang melakukan kegiatan praktikum,mengumpulkan dan mengolah data kurang teliti sehingga tidak sesuai dengan yang diharapkan.

Hasil yang diperoleh pada siklus II secara umum sudah menunjukkan peningkatan dibandingkan siklus I disebabkan karena 1) siswa diberi motivasi untuk dapat berperan aktif dalam pembelajaran; 2) siswa diberi kesempatan untuk bertanya materi yang belum dipahami; 3) guru berkeliling ke kelompok untuk memastikan semua siswa sudah paham pada materiyang sedang dipelajari; 4) siswa diberikan latihan soal yang lebih variatif. Hal ini sejalan dengan temuan- temuan peneliti lain seperti yang dilakukan oleh Puspitadewi (2016) yang pada dasarnya menyatakan bahwa model pembelajaran discovery Learning dapat meningkatkan hasil belajar siswa.Pembelajaran model discovery Learning menekankan pada pembentukan pengetahuan siswa dari pengalaman selama pembelajaran.

Hasil penelitian ini juga diperkuat oleh penelitian yang dilakukan oleh ( Susiyanti,2019) yang menyatakan bahwa pembelajaran dengan model pembelajaran discovery Learning menjadikan siswa aktif dan berpikir kritis dalam pemecahan masalah di kegiatan pembelajaran sehingga dapat meningkatkan hasil belajar siswa.

\section{KESIMPULAN}

Berdasarkan hasil penelitian tindakan kelas yang telah dilakukan selama dua siklus terbukti bahwa penerapan model discovery Learning menunjukkan adanya peningkatan hasil belajar siswa kelas XI MIPA- 3 SMAN 2 Jember dan penerapan model discovery Learning merupakan variasi dari model pembelajaran yang menggunakan pendekatan saintifik atau pendekatan berbasis keilmuan.

Dengan penerapan discovery Learning bisa lebih menekankan pada ditemukannya konsep atau prinsip yang sebelumnya tidak diketahui, masalah yang dihadapkan pada siswa bukan hasil rekayasa sehingga siswa harus mengerahkan seluruh pikiran dan keterampilannya untuk mendapatkan temuan- temuan didalam masalah itu melalui proses penelitian yang pada akhirnya hasil belajar siswa akan meningkat. Discovery Learning mendorong dan menginspirasi siswa berpikir secara kritis, analitis dan tepat dalam mengidentifikasi, memahami, memecahkan masalah dan mengaplikasikan materi pembelajaran. Peneliti menyarankan kepada rekan- rekan guru untuk menggunakan model pembelajaran discovery Learning dalam menyampaikan materi kimia untuk meningkatkan hasil belajar, karena guru mendorong siswa untuk mengidentifikasi apa yang ingin diketahui kemudian mencari informasi sendiri yang akhirnya mengorganisasi atau membentuk apa yang mereka ketahui dan mereka pahami dalam suatu bentuk akhir.

\section{DAFTAR PUSTAKA}

Fitriyah, Ari Murtadlo \& Rini Warti (2015). Pengaruh Model Pembelajaran Discovery Learning terhadap Hasil Belajar Matematika Siswa MAN Model Kota Jambi.

Halimatus Sa'diah, M. Kusasi, Abdul Hamid, (2017), Meningkatkan Aktivitas dan Hasil Belajar Menggunakan Kolabarosi Model Discovery Learning dan Number Head Together pada Materi Hidrolisis Garam di SMA Negeri 12 Banjarmasin. JCAE Journal of Chemistry and Education, Vol. 1 No.1, 2017, p.52-57 
Vol. 1 No. 2 September 2021 e-ISSN : 2797-3344 P-ISSN : 2797-3336

Kadri, M \& Rahmawati, M (2015). Pengaruh Model Pembelajaran Discovery Learning terhadap Hasil Belajar Siswa Pada Materi Pokok Bahasan Suhu dan Kalor. Jurnal Ikatan Alumni Fisika Unimed. Vol.1

Kemmis, S \& MC. Taggart, R (1988). The Action Research Planner. Victoria. Deakin University Press.

Rizky, P, Agung, N \& Ashadi (2016). Penerapan Model Pembelajaran Discovery Learning Untuk Meningkatkan Minat dan Prestasi Belajar Siswa Pada Materi Kelarutan dan Hasil Kali Kelarutan Kelas XI MIA 3 Semester Genap SMAN 1 Teras Tahun Pelajaran 2015/2016.Jurnal Pendidikan Kimia (JPK),Vol 5 No.4 Tahun 2016, Program Studi Pendidikan Kimia Universitas Sebelas Maret, Hal. 114-119.

Sardiman A.M. (2008). Interaksi dan Motivasi Belajar Mengajar,Jakarta, Raja Grafindo Persada

Sudjana, Nana (2010). Penilaian Hasil Proses Belajar Mengajar. (Cet.XV). Bandung: PT.Ramaja Rosdakarya.

Susiyanti (2019). Penerapan Model Pembelajaran Discovery Learning Melalui Pendekatan Saintifik Untuk Meningkatkan Hasil Belajar Siswa Kelas 2 Di SD Negeri 011 Titian Resak.Jurnal Inovasi Pendidikan Dasar Vol.1 No.4. Oktober 2021 P-ISSN: 27748014,e-ISSN:2774-7034.

Trianto (2009). Mendesain Model Pembelajaran Inovatif- Progresif. Surabaya : Kencana. 